Click www.researchjournal.co.in/online/subdetail.html to purchase.

INTERNATIONAL JOURNAL OF PLANT PROTECTION

VOLUME 13 | ISSUE 2 | OCTOBER, 2020 | 211-226

- ISSN-0974-2670 | Visit us : www.researchjournal.co.in

\title{
Diseases, moulds, insect-pests and mites of mushroom
}

\author{
Durga Prasad* and Ramji Singh ${ }^{1}$
}

Department of Plant Pathology, Banda University of Agriculture and Technology, Banda (U.P.) India

${ }^{1}$ Department of Plant Pathology, S.V.P. University of Agriculture and Technology, Meerut (U.P.) India

\section{ARITCLE INFO}

Received : 29.07 .2020

Accepted : 26.09 .2020

\section{KEY WORDS :}

Mushroom, Cob web, Dry bubble, Trichoderma blotch, False truffle, Sciarid, Phorids
*Corresponding author:

Email : dp.shubh@gmail.com

\begin{abstract}
Mushroom is defined as macro-fungus with distinctive edible fruiting body which can be either epigeous or hypogeous. Cultivation of edible mushrooms carries great relevance in todays' world in the context of a burgeoning population growth and extreme pressure on the environment. Mushrooms are highly nutritious and environment friendly crops that carry numerous medicinal benefits. The intensive cultivations of edible mushrooms can often be affected by several insect-pests and diseases caused by fungi, bacteria, viruses, nematodes etc. that rather frequently cause dramatic production loss. The market price of edible mushrooms is also reduced due mould's contaminations. These infestations, infections and contaminations are facilitated by the particular environmental conditions under which mushroom cultivation is commonly carried out. There is not much bibliographic information related to such stresses of mushrooms and their management. The updated review presents a practical checklist of diseases and pests of the mushroom, providing useful information that may help different users.
\end{abstract}

How to view point the article : Prasad, Durga and Singh, Ramji (2020). Diseases, moulds, insect-pests and mites of mushroom. Internat. J. Plant Protec., 13(2) : 211-226, DOI : 10.15740/ HAS/IJPP/13.2/211-226, Copyright@2020: Hind Agri-Horticultural Society. 